\title{
Perbedaan Kepuasan Perawat dalam Pendokumentasian Asuhan Keperawatan Berbasis Komputerisasi dan Manual (Studi di RS Paru dan RS Baladhika Husada Kabupaten Jember) (The Different of Nursing Satisfaction by Computerized Nursing Documentation and Manual Nursing Documentation [Study in Paru Hospital and Baladhika Husada Hospital Subdistrict at Jember])
}

\author{
Yunita Selly Santoso, Dodi Wijaya, Retno Purwandari \\ Fakultas Keperawatan, Universitas Jember \\ JI. Kalimantan No. 37 Kampus Tegal Boto Jember Telp./Fax. (0331)323450 \\ e-mail : dodi.wijaya@unej.ac.id
}

\begin{abstract}
Nursing documentation is the important thing that must be done by a nurse. There are two kind of nursing documentation, computerized nursing documentation and manual nursing documentation. This research purposes to find out the different of nursing satisfaction by computerized nursing documentation and manual nursing documentation. Crosssectional design was used in this research. Sampling technique used simple random sampling. Total of sample was 30 respondents and devided by 2 groups who used computerized nursing documentation and who used manual nursing documentation. Data was analyzed by Mann Whitney. The result showed nurse who used computerized nursing documentation have very satisfactied category (100\%). Nurse who used manual nursing documentation have very satisfactied category (100\%). The result of statistic analyze showed that $p$ Value (1.000)>alpha (0.05), that means there wasn't differences of nursing satisfaction by computerized nursing documentation and manual nursing documentation (study in Paru Hospital and Baladhika Husada Hospital Subdistrict at Jember). The reason why nursing satisfaction by manual nursing documentation have very satisfactied category, because it could ease in used of than computerized nursing documentation.
\end{abstract}

Keywords: computerized nursing documentation, manual nursing documentation, satisfaction 


\begin{abstract}
Abstrak
Pendokumentasian asuhan keperawatan merupakan hal penting yang harus dilakukan oleh seorang perawat. Terdapat dua macam pendokumentasian asuhan keperawatan, pendokumentasian asuhan keperawatan berbasis komputerisasi dan manual. Penelitian ini bertujuan untuk mencari perbedaan kepuasan perawat dalam pendokumentasian asuhan keperawatan berbasis komputerisasi dan manual. Desain crossectional digunakan pada penelitian ini. Teknik sampling yang digunakan adalah simple random sampling. Jumlah sampel sebanyak 30 responden dan dibagi menjadi 2 kelompok yang menggunakan pendokumentasian asuhan keperawatan berbasis komputerisasi dan manual. Data dianalisis menggunakan Mann Whitney. Hasil menunjukkan bahwa perawat yang menggunakan pendokumentasian asuhan keperawatan berbasis komputerisasi berada pada kategori sangat puas (100\%). Perawat yang menggunakan pendokumentasian asuhan keperawatan manual berada pada kategori sangat puas $(100 \%)$. Hasil analisis statistik menunjukkan bahwa $p$ value $(1,000)>$ alpha $(0,05)$, ini berarti tidak ada perbedaan kepuasan perawat dalam pendokumentasian asuhan keperawatan berbasis komputerisasi dan manual (studi di RS Paru dan RS Baladhika Husada Kabupaten Jember). Salah satu alasan mengapa kepuasan perawat dalam pendokumentasian asuhan keperawatan manual berada pada kategori sangat puas karena pendokumentasian ini mudah untuk digunakan dibandingkan pendokumentasian asuhan keperawatan berbasis komputerisasi.
\end{abstract}

Kata Kunci: pendokumentasian asuhan keperawatan berbasis komputerisasi, pendokumentasin asuhan keperawatan manual, kepuasan

\section{Pendahuluan}

Kemajuan IPTEK merupakan salah satu tantangan yang paling dirasakan perawat, khususnya pada sistem pendokumentasian asuhan keperawatan. Dokumentasi asuhan keperawatan adalah bukti pencatatan dan pelaporan yang dimiliki perawat dalam melakukan asuhan keperawatan yang berguna untuk kepentingan pasien, perawat dan tim kesehatan dalam memberikan pelayanan dengan dasar komunikasi yang akurat dan lengkap secara tertulis dengan tanggung jawab perawat [1]. Saat ini ada dua sistem pendokumentasian asuhan keperawatan, yaitu sistem pendokumentasian asuhan keperawatan berbasis komputerisasi dan manual[2]. Kebijakan penggunaan sistem pendokumentasian asuhan keperawatan oleh rumah sakit dinilai sebagai langkah untuk meningkatkan kepuasan kerja perawat dalam bekerja.

Kepuasan kerja merupakan suatu cara pandang seseorang, baik yang bersifat positif maupun bersifat negatif tentang pekerjaannya [3]. Seseorang dengan tingkat kepuasan kerja tinggi menunjukkan sikap yang positif terhadap pekerjaan itu. Sedangkan seseorang yang tidak puas dengan pekerjaannya menunjukkan sikap yang negatif terhadap pekerjaan itu [4].

Faktor yang mempengaruhi kepuasan, antara lain: kecerdasan, kecakapan, jenis kelamin, kondisi fisik, pendidikan, pengalaman kerja, masa kerja, dan sifat kerja [5]. Faktor utama lain yang mempengaruhi kepuasan kerja, antara lain: pekerjaan itu sendiri, upah/gaji, promosi, supervisi, kelompok kerja, dan kondisi kerja atau lingkungan kerja, pengawasan, ketentraman kerja, kondisi kerja, dan kesempatan untuk maju $[6,7]$.

Hasil studi pendahuluan yang dilakukan di RS Paru Jember menunjukkan bahwa saat ini rumah sakit telah menerapkan sistem pendokumentasian asuhan keperawatan berbasis komputerisasi dalam bentuk SIMRS (Sistem Informasi Manajemen Rumah Sakit). Terdapat format baku dalam pendokumentasian asuhan keperawatannya tetapi masih ada beberapa kekurangan yaitu dalam hal kelengkapan pendokumentasian asuhan keperawatan pada standar II (diagnosa keperawatan) dan standar III (intervensi keperawatan). Hasil studi pendahuluan kedua yang dilakukan di RS Baladhika Husada menunjukkan bahwa saat ini rumah sakit masih menerapkan sistem pendokumentasian asuhan keperawatan manual. Terdapat format baku dalam pendokumentasian asuhan keperawatan. Kelengkapan dalam pengisian proses pendokumentasian asuhan keperawatan sudah memenuhi standar.

Hasil penelitian oleh Malini (2008) bahwa tingkat kepuasan perawat terhadap aplikasi software dalam asuhan keperawatan adalah sangat puas (64\%) dan puas (36\%) [8]. Berbeda dengan hasil penelitian oleh Yanidrawati, Susilaningsih,dan Somantri (2012) bahwa tingkat kepuasan perawat dalam pendokumentasian asuhan keperawatan 
Santoso, et al, Perbedaan Kepuasan Perawat dalam Pendokumentasian Asuhan Keperawatan...

(manual) adalah puas $(7,04 \%)$ dan tidak puas $(92,96 \%)$ [9].

Berdasarkan hasil penelitian di atas menunjukkan bahwa terdapat perbedaan kepuasan dalam pendokumentasian asuhan keperawatan berbasis komputerisasi dan manual. Penelitian ini dimaksudkan untuk mengetahui apakah ada perbedaan kepuasan perawat dalam pendokumentasian asuhan keperawatan berbasis komputerisasi dan manual di RS Paru dan RS Baladhika Husada kabupaten Jember.

\section{Metode Penelitian}

Penelitian ini menggunakan desain deskriptif komparatif dengan bentuk pendekatan rancangan cross sectional. Dilakukan dengan teknik probability sampling menggunakan simple random sampling. Sasaran penelitian adalah perawat di ruang rawat inap RS Paru dan RS Baladhika Husada Kabupaten Jember sebanyak 30 responden pada masing-masing rumah sakit. Penelitian dilakukan di ruang rawat inap RS Paru dan RS Baladhika Husada Kabupaten Jember pada bulan Mei dan Juni 2015. Teknik pengumpulan data dilakukan menggunakan kuesioner MSQ dengan 8 dari 20 indikator kepuasan, antara lain: kecakapan (ability utilization), bentuk aktifitas (actifity), kemajuan dan perkembangan (advancement), bentuk kompensasi (compensation), tanggung jawab (responsibility), perasaan social (social service), dan bantuan serta bimbingan teknis (supervisiontechnique).

Data dianalisis menggunakan uji mannwhitney untuk mengetahui perbedaan kepuasan perawat dalam pendokumentasian asuhan keperawatan berbasis komputerisasi dan manual (studi di RS Paru dan RS Baladhika Husada kabupaten Jember).

\section{Hasil Penelitian}

Tabel 1. Rerata usia perawat di RS Baladhika Husada dan RS Paru kabupaten Jember $(n=30)$

\begin{tabular}{lccc}
\hline & Median & Min & Max \\
\hline $\begin{array}{l}\text { RS Baladhika } \\
\text { Husada }\end{array}$ & 31,00 & 24 & 52 \\
\hline RS Paru & 28,60 & 21 & 41 \\
\hline
\end{tabular}

Tabel 2. Distribusi frekuensi responden berdasarkan jenis kelamin dan tingkat pendidikan

\begin{tabular}{|c|c|c|c|c|}
\hline \multicolumn{3}{|c|}{ RS Baladhika Husada } & \multicolumn{2}{|c|}{ RS Paru } \\
\hline & \multicolumn{4}{|c|}{ Jenis Kelamin } \\
\hline & Frek & Pres & Frek & Pers \\
\hline Laki-laki & 17 & $56,7 \%$ & 11 & $36,7 \%$ \\
\hline Perempuan & 13 & $43,3 \%$ & 19 & $63,3 \%$ \\
\hline \multirow[t]{2}{*}{ Total } & 30 & $100 \%$ & 30 & $100 \%$ \\
\hline & \multicolumn{4}{|c|}{ Tingkat pendidikan } \\
\hline $\begin{array}{l}\text { DIII } \\
\text { Keperawatan }\end{array}$ & 26 & $86,7 \%$ & 21 & $70,0 \%$ \\
\hline $\begin{array}{l}\text { DIV } \\
\text { Keperawatan }\end{array}$ & 0 & $0 \%$ & 0 & $0 \%$ \\
\hline $\begin{array}{l}\text { S1 } \\
\text { Keperawatan / } \\
\text { Ners }\end{array}$ & 4 & $13,3 \%$ & 9 & $30,0 \%$ \\
\hline Total & 30 & $100 \%$ & 30 & $100 \%$ \\
\hline
\end{tabular}

Tabel 3. Distribusi frekuensi kepuasan perawat di RS Baladhika Husada dan RS Paru kabupaten Jember

\begin{tabular}{|c|c|c|c|c|c|}
\hline \multirow[b]{2}{*}{ Indikator } & \multirow[b]{2}{*}{ Kategori } & \multicolumn{2}{|c|}{$\begin{array}{c}\text { RS } \\
\text { Baladhika } \\
\text { Husada }\end{array}$} & \multicolumn{2}{|c|}{ RS Paru } \\
\hline & & $\begin{array}{l}\mathrm{Fr} \\
\mathrm{ek}\end{array}$ & $\begin{array}{c}\text { Pers } \\
(\%)\end{array}$ & Frek & $\begin{array}{c}\text { Pres } \\
(\%)\end{array}$ \\
\hline \multirow[t]{5}{*}{$\begin{array}{l}\text { Ability } \\
\text { utilization } \\
\text { (kecakapan) }\end{array}$} & $\begin{array}{l}\text { Sangat } \\
\text { tidak } \\
\text { puas }\end{array}$ & 0 & 0 & 0 & 0 \\
\hline & $\begin{array}{l}\text { Tidak } \\
\text { Puas }\end{array}$ & 0 & 0 & 0 & 0 \\
\hline & $\begin{array}{l}\text { Kurang } \\
\text { Puas }\end{array}$ & 0 & 0 & 0 & 0 \\
\hline & Puas & 2 & 6,7 & 0 & 0 \\
\hline & $\begin{array}{l}\text { Sangat } \\
\text { Puas }\end{array}$ & 28 & 93,3 & 30 & 100 \\
\hline Total & & 30 & 100 & 30 & 100 \\
\hline \multirow[t]{4}{*}{$\begin{array}{l}\text { Activity } \\
\text { (aktifitas) }\end{array}$} & $\begin{array}{l}\text { Sangat } \\
\text { tidak } \\
\text { puas }\end{array}$ & 0 & 0 & 0 & 0 \\
\hline & $\begin{array}{l}\text { Tidak } \\
\text { Puas }\end{array}$ & 0 & 0 & 0 & 0 \\
\hline & $\begin{array}{l}\text { Kurang } \\
\text { Puas }\end{array}$ & 0 & 0 & 0 & 0 \\
\hline & $\begin{array}{l}\text { Puas } \\
\text { Sangat } \\
\text { Puas }\end{array}$ & $\begin{array}{c}0 \\
30\end{array}$ & $\begin{array}{c}0 \\
100\end{array}$ & $\begin{array}{c}1 \\
29\end{array}$ & $\begin{array}{c}3,3 \\
96,7\end{array}$ \\
\hline Total & & 30 & 100 & 30 & 100 \\
\hline $\begin{array}{l}\text { Advancement } \\
\text { (perkembanga } \\
\mathrm{n} \quad \text { dan }\end{array}$ & $\begin{array}{l}\text { Sangat } \\
\text { tidak } \\
\text { puas }\end{array}$ & 0 & 0 & 0 & 0 \\
\hline \multirow[t]{4}{*}{ kemajuan) } & $\begin{array}{l}\text { Tidak } \\
\text { Puas }\end{array}$ & 0 & 0 & 0 & 0 \\
\hline & $\begin{array}{l}\text { Kurang } \\
\text { Puas }\end{array}$ & 0 & 0 & 1 & 3,3 \\
\hline & Puas & 0 & 0 & 0 & 0 \\
\hline & $\begin{array}{l}\text { Sangat } \\
\text { Puas }\end{array}$ & 30 & 100 & 29 & 96,7 \\
\hline Total & & 30 & 100 & 30 & 100 \\
\hline
\end{tabular}


Santoso, et al, Perbedaan Kepuasan Perawat dalam Pendokumentasian Asuhan Keperawatan...

\begin{tabular}{|c|c|c|c|c|c|}
\hline \multirow[t]{7}{*}{$\begin{array}{l}\text { Compensation } \\
\text { (kompensasi) }\end{array}$} & $\begin{array}{l}\text { Sangat } \\
\text { tidak }\end{array}$ & 0 & 0 & 0 & 0 \\
\hline & puas & & & & \\
\hline & Tidak & 0 & 0 & 0 & 3,3 \\
\hline & Puas & & & & \\
\hline & Kurang & 0 & 0 & 1 & 13,3 \\
\hline & Puas & 5 & 16,7 & 4 & 83,3 \\
\hline & $\begin{array}{l}\text { Sangat } \\
\text { Puas }\end{array}$ & 25 & 83,3 & 25 & \\
\hline Total & & 30 & 100 & 30 & 100 \\
\hline \multirow[t]{7}{*}{$\begin{array}{l}\text { Co-workers } \\
\text { (rekan kerja) }\end{array}$} & $\begin{array}{l}\text { Sangat } \\
\text { tidak }\end{array}$ & 9 & 30 & 23 & 76,7 \\
\hline & puas & & & & \\
\hline & Tidak & 18 & 60 & 0 & 0 \\
\hline & Puas & & & & \\
\hline & Kurang & 0 & 0 & 0 & 0 \\
\hline & Puas & 0 & 0 & 7 & 23,3 \\
\hline & $\begin{array}{l}\text { Sangat } \\
\text { Puas }\end{array}$ & 3 & 10 & 0 & 0 \\
\hline Total & & 30 & 100 & 30 & 100,0 \\
\hline \multirow{8}{*}{$\begin{array}{l}\text { Responsibility } \\
\text { (tanggung } \\
\text { jawab) }\end{array}$} & $\begin{array}{l}\text { Sangat } \\
\text { tidak }\end{array}$ & 0 & 0 & 1 & 3,3 \\
\hline & puas & & & & \\
\hline & Tidak & 0 & 0 & 0 & 0 \\
\hline & Puas & & & & \\
\hline & Kurang & 0 & 0 & 5 & 16,7 \\
\hline & Puas & & & & \\
\hline & Puas & 0 & 0 & 0 & 0 \\
\hline & $\begin{array}{l}\text { Sangat } \\
\text { Puas }\end{array}$ & 30 & 100 & 24 & 80 \\
\hline Total & & 30 & 100 & 30 & 100 \\
\hline \multirow{7}{*}{$\begin{array}{l}\text { Social service } \\
\text { (perasaan } \\
\text { social) }\end{array}$} & $\begin{array}{l}\text { Sangat } \\
\text { tidak }\end{array}$ & 0 & 0 & 0 & 0 \\
\hline & puas & & & & \\
\hline & Tidak & 0 & 0 & 0 & 0 \\
\hline & Kurang & 0 & 0 & 5 & 16,7 \\
\hline & Puas & & & & \\
\hline & Puas & 1 & 3,3 & 0 & 0 \\
\hline & $\begin{array}{l}\text { Sangat } \\
\text { Puas }\end{array}$ & 29 & 96,7 & 25 & 83,3 \\
\hline Total & & 30 & 100 & 30 & 100 \\
\hline \multirow{8}{*}{$\begin{array}{l}\text { Supervision- } \\
\text { technical } \\
\text { (bimbingan dan } \\
\text { bantuan teknis) }\end{array}$} & $\begin{array}{l}\text { Sangat } \\
\text { tidak }\end{array}$ & 0 & 0 & 0 & 0 \\
\hline & puas & & & & \\
\hline & Tidak & 0 & 0 & 0 & 0 \\
\hline & Puas & & & & \\
\hline & Kurang & 0 & 0 & 1 & 3,3 \\
\hline & Puas & & & & \\
\hline & Puas & 1 & 3,3 & 0 & 0 \\
\hline & $\begin{array}{l}\text { Sangat } \\
\text { Puas }\end{array}$ & 29 & 96,7 & 29 & 96,7 \\
\hline \multicolumn{2}{|l|}{ Total } & 30 & 100 & 30 & 100 \\
\hline
\end{tabular}

Tabel 4. Distribusi frekuensi perbedaan kepuasan perawat dalam pendokumentasian asuhan keperawatan berbasis komputerisasi dan manual di RS Baladhika Husada dan RS Paru kabupaten Jember

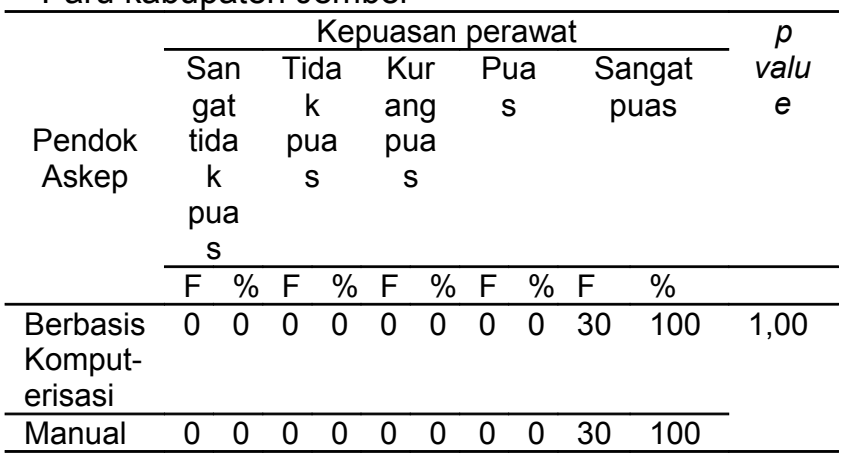

\section{Pembahasan}

Terdapat hubungan yang tidak konsisten antara umur dengan kepuasan kerja [4]. Usia pekerja merupakan salah satu faktor yang mempengaruhi kepuasan pekerja. Pada pekerja professional, semakin meningkatnya usia semakin meningkat pula kepuasan kerjanya. Hasil menunjukkan bahwa kepuasan perawat di RS Baladhika Husada lebih tinggi dibandingkan kepuasan perawat di RS Paru kabupaten Jember karena sebagian besar perawat di RS Baladhika Husada berada pada usia 31 tahun, sedangkan sebagian besar perawat di RS Paru berada pada usia 28 tahun.

Salah satu faktor yang mempengaruhi kepuasan perawat adalah jenis kelamin dan tingkat pendidikan [5]. Laki-laki cenderung lebih agresif dan lebih besar kemungkinannya dalam memiliki pengharapan untuk sukses, sehingga laki-laki cenderung mengalami ketidakpuasan dalam pekerjaannya dibandingkan perempuan. Hasil menunjukkan bahwa kepuasan perawat di RS Baladhika Husada lebih tinggi dibandingkan kepuasan perawat di RS Paru kabupaten Jember.

Perbedaan kepuasan perawat dalam pendokumentasian asuhan keperawatan berbasis komputerisasi dan manual di RS Paru dan RS Baladhika Husada Kabupaten Jember, dianalisis dengan uji mann whitney. Berdasarkan uji mann whitney menunjukkan bahwa perawat yang menggunakan pendokumentasian asuhan keperawatan berbasis komputerisasi berada pada kategori sangat puas sebesar $100 \%$. Sedangkan pada perawat yang menggunakan pendokumentasian asuhan keperawatan 
manual menunjukkan bahwa kepuasan perawat berada pada kategori sangat puas sebesar $100 \%$. Nilai $p$ value pada uji mann whitney sebesar 1,000 dapat disimpulkan bahwa tidak ada perbedaan kepuasan perawat dalam pendokumentasian asuhan keperawatan berbasis komputerisasi dan manual.

Hasil penelitian perbedaan kepuasan perawat dalam pendokumentasian asuhan keperawatan berbasis komputerisasi dan manual menunjukkan bahwa tidak ada perbedaan. Kepuasan perawat dalam pendokumentasian asuhan keperawatan berbasis komputerisasi dan manual berada pada kategori sangat puas. Kepuasan perawat yang melakukan pendokumentasian asuhan keperawatan berbasis komputerisasi bila ditinjau dari prosentase pada tiap indikator tidak ada perawat yang mempunyai ketidakpuasan dalam kecakapan, bentuk aktifitas, kemajuan dan perkembangan, kompensasi, rekan kerja, tanggung jawab, perasaan sosial, dan bimbingan serta bantuan teknis. Pada variabel total kepuasan terdapat $100 \%$ perawat berada pada kategori sangat puas.

Kepuasan perawat yang melakukan pendokumentasian asuhan keperawatan berbasis komputerisasi bila ditinjau dari prosentase pada tiap indikator tidak ada perawat yang mempunyai ketidakpuasan dalam kecakapan, bentuk aktifitas, kemajuan dan perkembangan, kompensasi, rekan kerja, tanggung jawab, perasaan sosial, dan bimbingan serta bantuan teknis. Pada variabel total kepuasan terdapat $100 \%$ perawat berada pada kategori sangat puas. Berdasarkan hasil analisis di RS baladhika Husada didapatkan bahwa penggunaan pendokumentasian asuhan keperawatan manual dirasa lebih memudahkan terutama dalam hal teknis penggunaannya.

Kesimpulan penelitian bahwa dari kedelapan indikator kepuasan perawat dalam pendokumentasian asuhan keperawatan berbasis komputerisasi dan manual yaitu kecakapan, bentuk aktifitas, perkembangan dan kemajuan, bentuk kompensasi, rekan kerja, tanggung jawab, perasaan sosial, dan bimbingan serta bantuan teknis berada pada kategori sangat puas, hal tersebut ditunjukkan dari hasil prosentase variabel kepuasan perawat bahwa terdapat 100\% perawat berada dalam kategori sangat puas. Hal ini ditunjang oleh terpenuhinya harapan, kebutuhan, dan keinginan sehingga kepuasan kerja perawat menjadi maksimal [10].

Hasil penelitian oleh Malini bahwa tingkat kepuasan perawat terhadap aplikasi software dalam asuhan keperawatan adalah sangat puas $(64 \%)$ dan puas (36\%) [8]. Berbeda dengan hasil penelitian oleh Yanidrawati, Susilaningsih,dan Somantri bahwa tingkat kepuasan perawat dalam pendokumentasian asuhan keperawatan (manual) adalah puas (7,04\%) dan tidak puas $(92,96 \%)$ [9]. Berdasarkan penelitian tersebut didapatkan bahwa tingkat kepuasan perawat dalam pendokumentasian asuhan keperawatan (manual) sebagian besar berada dalam kategori tidak puas.

Berbeda dengan hasil dari penelitian yang telah dilakukan peneliti. Salah satu faktor yang mempengaruhi kepuasan perawat dalam pendokumentasian asuhan keperawatan manual berada pada kategori sangat puas karena pendokumentasian tersebut dinilai lebih memudahkan dalam penggunaannya. Metode manual diyakini perawat menjadi metode yang sangat mudah dipahami oleh semua lapisan perawat baik laki-laki, perempuan, dan seluruh latar belakang tingkat pendidikan perawat di RS Baladhika Husada kabupaten Jember.

\section{Simpulan dan Saran}

Hasil penelitian didapatkan bahwa tidak ada perbedaan kepuasan perawat dalam pendokumentasian asuhan keperawatan berbasis komputerisasi dan manual (study di RS Paru dan RS Baladhika Husada kabupaten Jember). Didapatkan bahwa tingkat kepuasan perawat dalam pendokumentasian asuhan keperawatan berbasis komputerisasi di RS Paru kabupaten Jember menunjukkan responden berada pada kategori sangat puas $100 \%$. Sama halnya dengan tingkat kepuasan perawat dalam pendokumentasian asuhan keperawatan manual di RS baladhika Husada kabupaten Jember menunjukkan responden berada pada kategori sangat puas $100 \%$. Hasil penelitian ini dapat dijadikan masukan bagi rumah sakit untuk lebih meningkatkan kepuasan perawat terutama dalam pendokumentasian asuhan keperawatan yang diterapkan, selain itu perlu adanya peningkatan peran perawat sebagai advocate dan case manager. Saran bagi penelitian selanjutnya adalah adanya pengembangan riset mengenai beban kerja perawat, komitmen organisasi dalam pendokumentasian asuhan keperawatan berbasis komputerisasi dan manual. 


\section{Daftar Pustaka}

[1] Hidayat A. Pengantar kebutuhan dasar manusia: aplikasi konsep dan proses keperawatan. Buku 2. Jakarta: Salemba Medika; 2009

[2] Susanti M. Modul pendokumentasian asuhan keperawatan. Padang: Pelatihan Manajemen Keperawatan di RSUD dr. Rasidin Padang; 2011

[3] Siagian SP. Manajemen sumber daya manusia. Jakarta: Bumi Aksara; 2006

[4] Robbins SP. Perilaku organisasi. Jakarta: PT Indeks Kelompok Gramedia; 2001

[5] Mangkunegara PAA. Manajemen sumber daya manusia. Bandung: Remaja Rodakarya; 2009

[6] Luthans F. Perilaku organisasi, Edisi sepuluh. Yogyakarta: Penerbit Andy; 2005

[7] As'ad. Kepemimpinan efektif dalam perusahaan. Edisi 2. Yogyakarta: Liberty; 2003

[8] Malini H. Aplikasi software asuhan keperawatan untuk meningkatkan kepuasan kerja perawat; 2008

[9] Yanidrawati S, Somantri. [internet]. 2012. FIK Universitas Padjajaran: Hubungan kepuasan kerja dengan kinerja perawat di Ruang Rawat Inap Rumah Sakit Umum Daerah Kabupaten Bekasi. [diambil tanggal 30 Juli 2015] Available from: http://jurnal.unpad.ac.id/ejournal/article/do wnload/753/799

[10] Umar H. Sumber daya manusia dalam organisasi. Jakarta: PT Gramedia Pustaka Utama; 2008 